\title{
Ecology of Cladocera species from Central America based on subfossil assemblages
}

\author{
Marta Wojewódka, ${ }^{1 *}$ Edyta Zawisza, ${ }^{1}$ Sergio Cohuo, ${ }^{2}$ Laura Macario-González, ${ }^{2}$ Antje Schwalb,${ }^{2}$ Izabela Zawiska, ${ }^{3}$ \\ Liseth Pérez ${ }^{4}$ \\ ${ }^{1}$ Institute of Geological Sciences, Research Centre in Warsaw, Polish Academy of Sciences, Twarda 51/55, 00818 Warsaw, Poland; \\ ${ }^{2}$ Institut für Geosysteme und Bioindikation, Technische Universität Braunschweig, Langer Kamp 19c, 38106 Braunschweig, Germany; \\ ${ }^{3}$ Institute of Geography and Spatial Organization, Polish Academy of Sciences, Twarda 51/55, 00818 Warsaw, Poland; ${ }^{4}$ Instituto de \\ Geología, Universidad Nacional Autónoma de México (UNAM), Ciudad Universitaria, 04510, Ciudad de México, México
}

*Corresponding author: m.wojed@twarda.pan.pl

\begin{abstract}
Cladocera species composition was analyzed in surface sediments of 29 lakes in Central America (Guatemala, El Salvador and Honduras). The material studied was collected with an Ekman grab in autumn 2013 from lakes located in lowland, highland and mountain regions. The study revealed high variability in qualitative and quantitative composition of subfossil Cladocera. A total of $31 \mathrm{Cladocera}$ species (5 planktonic and 26 littoral) were identified, as well as 4 morphotypes that could not be identified (NRR 1-4). Planktonic Bosminidae and Daphniidae were the most abundant families. Daphniidae were restricted to water bodies in mountain regions, whereas Bosminidae were widely distributed in lakes with different abiotic conditions. Moreover, Bosminidae species also occurred in highly mineralized waters ( $>$ $900 \mu \mathrm{S} \mathrm{cm}^{-1}$ ). The great majority of the identified Cladocera species belonged to the littoral family Chydoridae. Chydorus cf. sphaericus was the most common species (found in 20 lakes), which probably reflects its tolerance to a wide spectrum of habitat conditions. Cluster analysis discriminated 6 groups of Cladocera species with a high correlation level within groups $(\geq 0.8)$, which showed different types of correlation with lake characteristics and environmental variables. Canonical correspondence analysis (CCA) showed that altitude and secondly water electrical conductivity were the most important drivers of Cladocera species composition in the region studied. Furthermore, CCA analysis indicated lowland lakes with low water transparency were also characterized by peculiar species assemblages.
\end{abstract}

Key words: Subfossil Cladocera; Central America; waterfleas ecology; Guatemala; El Salvador; Honduras.

Received: September 2016. Accepted: November 2016.

\section{INTRODUCTION}

Cladocera are one of the most important components of zooplankton in lacustrine ecosystems. This group is also well-known to promptly respond to environmental changes (Jeppesen et al., 2001). Previous studies have highlighted that temperature and altitude are among the main factors determining Cladocera communities (Campanelli, Mortari and Henry, 2016; Green, 1995; Padhye et al., 2016; Sweetman, 2010; Zawiska et al., 2015). In addition, these studies have shown comparable sensitivities to changes in lake water trophic state, water depth, conductivity and $\mathrm{pH}$ (Korhola and Rautio, 2001). These responses to environmental variables makes Cladocera one of the most powerful paleolimnological indicators and for this reason they have been widely used for the reconstruction of past lacustrine environments (Bjerring, 2007; Kienast et al., 2011; Korosi, 2012; Luoto et al., 2009; Mirosław-Grabowska and Zawisza, 2014; Nováková et al., 2013 Sarmaja-Korjonen and Hyvärinen, 2008; Schmidt, 2000; Szeroczyńska, 1991; Szeroczyńska et al., 2007; Szeoczyńska and Zawisza, 2011 a,b). Subfossil remains of Cladocera are commonly used in paleolimnological studies in Eurasia and America (Bjerring, 2007; Mirosław-Grabowska and Zawisza, 2014; Paterson, 1994; Szeroczyńska et al., 2007). However, only a few paleolimnological studies based on water fleas were conducted in Central America (Cuna et al., 2014; Szeroczyńska et al., 2015; Zawisza et al., 2012, 2014, 2016). So far, the majority of studies focused on the living Cladocera and their taxonomy (Elías-Gutiérrez et al., 1999, 2006, 2008; Sinev, 2015; Sinev and Silva-Briano, 2012; Sinev and Zawisza, 2013).

The knowledge of Cladocera species composition, distribution and ecology in freshwater lakes of Central America is crucial for the development of reliable bioindicators, and for paleolimnological investigations. The main objective of the present study was to analyze and identify subfossil Cladocera species in northern Central America, in particular in Guatemala, El Salvador and Honduras, and to explore their relationship to lake environmental characteristics such as altitude, lake area, depth, $\mathrm{pH}$, transparency, conductivity and dissolved oxygen. The obtained results will provide the basis for the reconstruction of regional and global climatic and envoronemntal changes at long-term scale. 


\section{METHODS}

\section{Study sites}

The study included 29 waterbodies located between $13^{\circ}$ and $17^{\circ} \mathrm{N}$ geographical latitude and from $87^{\circ}$ to $91^{\circ} \mathrm{W}$ longitude in Guatemala, El Salvador and Honduras (Fig. 1). The study area is located in the Central American Bioregion of the American Neotropical Ecozone, which is characterized by two distinct seasons: a dry winter and a moist summer season (Taylor and Alfaro, 2005). The subtropical ridge (belt of high atmospheric pressure) from the northern Atlantic is controlling the climate of the region, whereas the Intertropical Convergence Zone (ITCZ) and polar fronts of mid-latitude origin have a secondary impact (Taylor and Alfaro, 2005). One of the main factors affecting the microclimate of the area is topography (Karmalkar et al., 2011; Taylor and Alfaro, 2005). The considerable differences in mean annual temperature and precipitation which characterize the entire region mainly depend on altitude. The Guatemalan lowlands are characterized by a mean annual temperature of $25-28^{\circ} \mathrm{C}$, whereas temperatures in highland and mountain regions are around $12-15^{\circ} \mathrm{C}$ (Atlas Climatologico for 1928-2003, the National Institute for Seismology, Volcanology, Meteorology and Hydrology of Guatemala; www.insivumeh.gob.gt). Annual precipitation in the area varies considerably during the year and ranges from $<1000$ $\mathrm{mm}$ in the plains to $>2500 \mathrm{~mm}$ in the mountains (Taylor and Alfaro, 2005).

The lakes studied are located at altitudes ranging from sea level (El Muchacho at $3 \mathrm{~m}$ asl) to high altitude lakes (Magdalena and Chicabal at 2863 and $2726 \mathrm{~m}$ asl, respectively, Tab. 1). Lake area and depth also were quite variable. The largest lake were Atitlán and Yojoa (125 and $\sim 79 \mathrm{~km}^{2}$, respectively, Tab. 1), while several lakes have an area $<0.10 \mathrm{~km}^{2}$, such as Madre Vieja $\left(0.10 \mathrm{~km}^{2}\right)$, Verde

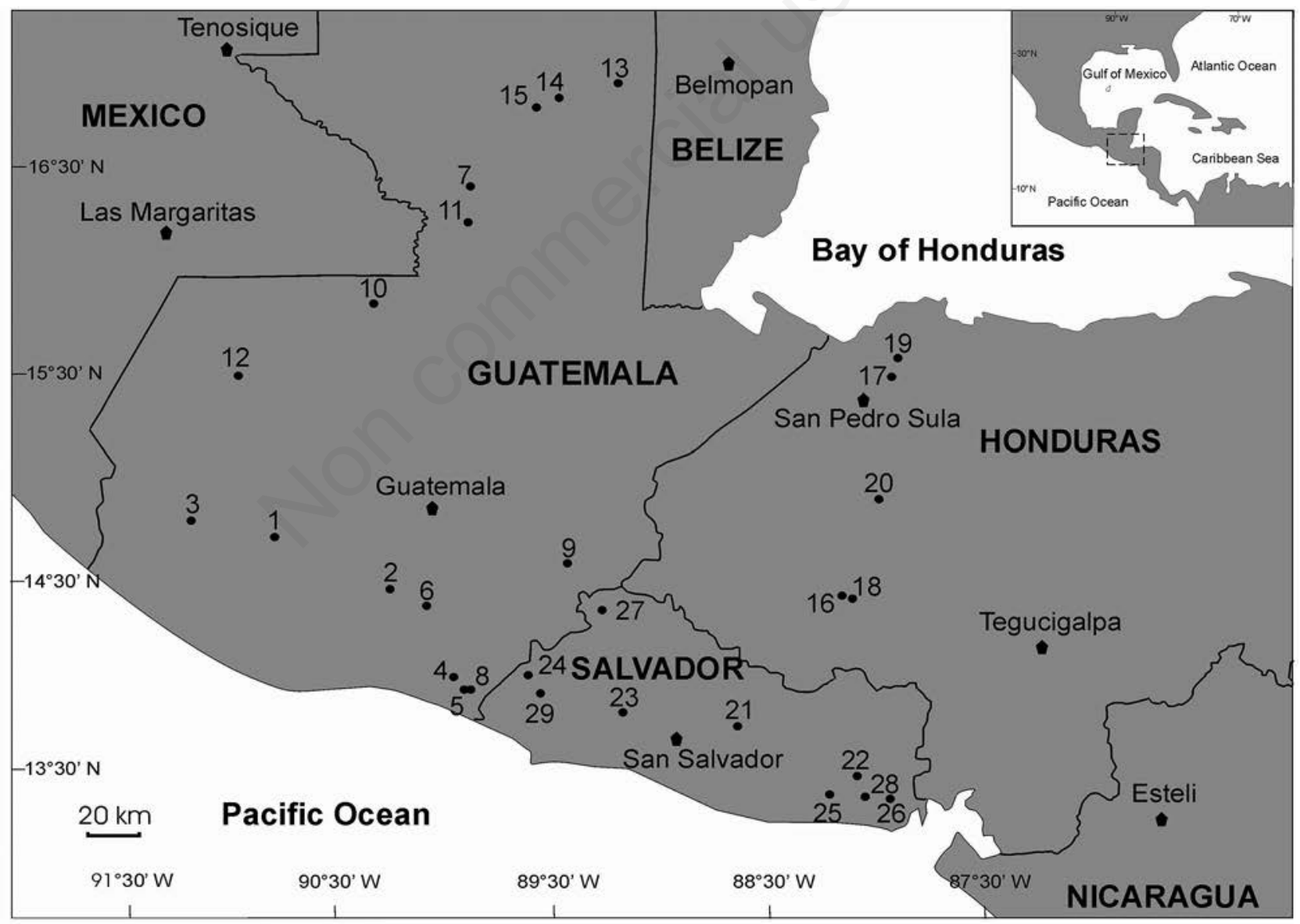

Fig. 1. Map of the study area showing the location of lakes sampled in Central America, i.e. Guatemala, Honduras and El Salvador. Numbers indicate the names of the lakes: 1, Atitlán; 2, Calderas; 3, Chicabal; 4, Comandador; 5, El Muchacho; 6, El Pino; 7, El Rosario; 8, Grande; 9, Ipala; 10, Lachuá; 11, Las Pozas; 12, Magdalena; 13, Sacnab; 14, Salpetén; 15, Quexil; 16, Chiligatoro; 17, Jucutuma; 18, Madre Vieja; 19, Ticamaya; 20, Yojoa; 21, Apastepeque; 22, Aramuaca; 23, Chanmico; 24, El Espino; 25, Jocotal; 26, Los Negritos; 27, Metapan; 28, Olomega; 29, Verde. 
$\left(0.10 \mathrm{~km}^{2}\right)$, Chiligatoro $\left(0.04 \mathrm{~km}^{2}\right)$, El Rosario $\left(0.02 \mathrm{~km}^{2}\right)$, Magdalena $\left(0.01 \mathrm{~km}^{2}\right)$ (Tab. 1). The study covered both very shallow ( $\leq 3 \mathrm{~m}$ depth, such as Comandador, El Muchacho, El Rosario, Grande, Magdalena, Jucutuma, Ticamaya, Jocotal, Los Negritos, Olomega), and very deep lakes (>300 m), such as Lachuá (a $378 \mathrm{~m}$ deep karstic lake), Atitlán (a 340 m deep crater lake) and Chicabal (330 m, Tab. 1).

\section{Sampling and analyses}

Sediments were collected in autumn 2013 using an Ekman sediment sampler. The geographical location of the lakes was determined by a handheld navigator (GPSmap 60c). Water transparency was determined using a Secchi disk, and the maximum lake depth was identified using a portable depth sounder (Echosounder Eagle Mach 1). Physical and chemical parameters of the surface waters (i.e., $\mathrm{pH}$, conductivity, dissolved oxygen) were measured with a WTW multi set $350 \mathrm{i}$ multiparametric probe. The area of each lake (Tab. 1) was calculated by the measure tool of Google Earth. Lake sediment samples were collected both from the littoral as well as from the open-water (pelagic) zone. In eight shallow lakes, where there was no pelagic zone (i.e., Comandador, El Muchacho, El Rosario, Grande, Jucutuma, Ticamaya, Jocotal, Los Negritos), samples were collected only from the littoral zone (Tab. 1). Lakes El Pino, Ipala, Quexil, Madre Vieja, Chanmico, El Espino, Metapan and Verde, were sampled only in the profundal zone due to the shape of the lake basin. Crater lake Aramuaca (107 m depth) was sampled only in the littoral zone (Tab. 1).

Tab. 1. Location, morphometry and selected limnological variables measured at water surface at the waterbodies sampled in Central America.

\begin{tabular}{|c|c|c|c|c|c|c|c|c|c|c|c|c|c|c|}
\hline ID & Name & Country & $\begin{array}{l}\text { Geog } \\
\text { coord }\end{array}$ & $\begin{array}{l}\text { aphic } \\
\text { inates }\end{array}$ & Altitude & Area & & & $\mathbf{Z}_{\max }$ & Secchi & $\mathrm{pH}$ & Conductivit & $\mathrm{y} \quad \mathrm{O}_{2}$ & $\mathrm{HCl}$ \\
\hline & & & $\mathbf{N}$ & W & (m asl) & $\left(\mathrm{km}^{2}\right)$ & $\mathbf{L}$ & $\mathbf{P}$ & $(\mathrm{m})$ & (m) & - & $\left(\mu \mathrm{S} \mathrm{cm} \mathrm{cm}^{-1}\right)$ & $\left(\mathrm{mgL}^{-1}\right)$ & \\
\hline 1 & Atitlán & Guatemala & 14.6837 & 91.2239 & 1556 & 125.00 & + & + & 340 & 4.2 & 8.9 & 442 & 5.7 & + \\
\hline 2 & Calderas & & 14.4117 & 90.5913 & 1790 & 0.35 & + & + & 26 & 2.9 & 9.2 & 100 & 4.9 & - \\
\hline 3 & Chicabal & & 14.7875 & 91.6561 & 2726 & 0.21 & + & + & 330 & 1.6 & 9.0 & 12 & 5.4 & - \\
\hline 4 & Comandador & & 13.9600 & 90.2544 & 20 & 0.65 & + & & 1.7 & 0.5 & 7.4 & 251 & 5.6 & - \\
\hline 5 & El Muchacho & & 13.8892 & 90.1918 & 3 & 0.36 & + & & 2 & 0.4 & 9.1 & 439 & 5.9 & - \\
\hline 6 & El Pino & & 14.3447 & 90.3941 & 1038 & 0.64 & & + & 18 & 2.8 & 8.3 & 100 & 2.0 & - \\
\hline 7 & El Rosario & & 16.5255 & 90.1601 & 126 & 0.02 & + & & 3 & 0.2 & 7.2 & 987 & 1.7 & + \\
\hline 8 & Grande & & 13.8903 & 90.1703 & 5 & 0.95 & + & & 2 & 0.2 & 7.4 & 110 & 3.7 & - \\
\hline 9 & Ipala & & 14.5571 & 89.6394 & 1495 & 0.56 & & + & 25 & 3.6 & 8.0 & 100 & 2.8 & - \\
\hline 10 & Lachuá & & 15.9184 & 90.6732 & 170 & 4.00 & + & & 378 & 4.4 & 7.9 & 906 & 4.8 & + \\
\hline 11 & Las Pozas & & 16.3432 & 90.1660 & 152 & 2.16 & + & + & 35 & 3.1 & 8.3 & 277 & 5.4 & + \\
\hline 12 & Magdalena & & 15.5426 & 91.3956 & 2863 & 0.01 & + & + & 3 & 2.8 & 8.8 & 331 & 6.2 & + \\
\hline 13 & Sacnab & & 17.0583 & 89.3725 & 170 & 4.28 & + & + & 9 & 1.8 & 9.0 & 412 & 6.1 & + \\
\hline 14 & Salpetén & & 16.9815 & 89.6755 & 105 & 2.77 & + & + & 32 & 1.7 & 7.0 & 4520 & 5.8 & + \\
\hline 15 & Quexil & & 16.9231 & 89.8099 & 120 & 2.20 & & + & 32 & 2.7 & 8.5 & 204 & 4.5 & - \\
\hline 16 & Chiligatoro & Honduras & 14.3756 & 88.1830 & 1925 & 0.04 & + & + & 5.5 & 0.9 & 7.4 & 100 & 1.9 & - \\
\hline 17 & Jucutuma & & 15.5123 & 87.9028 & 27 & 4.34 & + & & 2 & 2.0 & 7.3 & 100 & 1.0 & - \\
\hline 18 & Madre Vieja & & 14.3569 & 88.1376 & 1866 & 0.10 & & + & 3.4 & 0.9 & 8.5 & 100 & 2.7 & - \\
\hline 19 & Ticamaya & & 15.5506 & 87.8897 & 17 & 2.91 & + & & 2 & 0.8 & 7.2 & 100 & 1.6 & - \\
\hline 20 & Yojoa & & 14.8606 & 87.9847 & 639 & 79.70 & + & + & 22 & 3.3 & 8.3 & 100 & 2.7 & - \\
\hline 21 & Apastepeque & Salvador & 13.6925 & 88.7448 & 509 & 0.38 & + & + & 47 & 6.1 & 8.6 & 100 & 2.8 & - \\
\hline 22 & Aramuaca & & 13.4294 & 88.1065 & 76 & 0.40 & + & & 107 & 6.7 & 8.4 & 100 & 4.1 & - \\
\hline 23 & Chanmico & & 13.7786 & 89.3541 & 477 & 0.78 & & + & 51 & 0.9 & 9.2 & 100 & 3.4 & + \\
\hline 24 & El Espino & & 13.9530 & 89.8652 & 689 & 0.99 & & + & 5.5 & 0.4 & 8.5 & 85 & 6.6 & - \\
\hline 25 & Jocotal & & 13.3371 & 88.2519 & 26 & 8.70 & + & & 3 & 1.5 & 8.0 & 595 & 3.0 & - \\
\hline 26 & Los Negritos & & 13.2831 & 87.9370 & 102 & 0.69 & + & & 2 & 0.3 & 9.2 & 40 & 5.2 & - \\
\hline 27 & Metapan & & 14.3094 & 89.4655 & 450 & 16.00 & & + & 6 & 0.2 & 8.4 & 255 & 3.1 & - \\
\hline 28 & Olomega & & 13.3072 & 88.0551 & 66 & 25.20 & + & + & 2.5 & 0.9 & 7.7 & 105 & 2.5 & - \\
\hline 29 & Verde & & 13.8915 & 89.7872 & 1609 & 0.10 & & + & 12 & 2.7 & 7.5 & 83 & 4.5 & - \\
\hline
\end{tabular}

L, littoral zone; P, pelagic zone; $\mathrm{Z}_{\max }$, maximum lake depth; HCl, reaction with acid during preparation. The World Geodetic System of 1984 (WGS84) datum was used for the Cladocera samples. 
Sediment samples were placed in plastic bottles $(100 \mathrm{~mL})$ immediately after collection, and stored under refrigeration. Samples were then transported to the Paleolimnology Laboratory of Universidad National Autonomous de Mexico (UNAM), where subsamples for subfossil Cladocera analysis were obtained and preserved in cooling condition.

Subfossil Cladocera were analyzed at the Bioindicator Laboratory at the Warsaw Research Center of the Institute of Geological Sciences, the Polish Academy of Sciences. Each sample consisting of $1 \mathrm{~cm}^{3}$ of wet sediment was prepared according to standard methods (Frey, 1986). Sediments were treated with $10 \% \mathrm{HCl}$ to eliminate carbonate and then heated in $10 \% \mathrm{KOH}$ for $30 \mathrm{~min}$. The residue was centrifuged and sieved through a $38 \mu \mathrm{m}$ sieve, transferred into a test tube and filled up to $5 \mathrm{~cm}^{3}$ with distilled water. Samples were stained with safranin. Three to four slides obtained from of $0.1 \mathrm{~cm}^{3}$ liquid suspension each were examined at the microscope for each sample. The identification of Cladocera taxa followed Elías-Gutiérrez et al. (2006, 2008), Hudec (2000), Kotov (2009), Kotov et al. (2003), Rajapaksa and Fernando (1987), Rey and Vasquez (1986), Sinev (1998, 2001, 2015a, 2015b), Sinev and Dumont (2016), Sinev and Zawisza (2013), Van Damme et al. (2011). The Cladocera relative abundance diagram was prepared using the $\mathrm{C} 2$ program (Juggins 2005, 2007).

In order to determine the relation between species distribution and lake characteristics (area, altitude, maximum depth) and water variables ( $\mathrm{pH}$, Secchi transparency, dissolved oxygen), cluster analysis and canonical correspondence analysis (CCA; ter Braak, 1986) were performed. Cluster analysis is based on the similarity measure performed on qualitative data (Hammer et al., 2011), while CCA is a combination of mutual averaging algorithm with a multiple regression (ter Braak, 1986) which performed on combined quatitative Cladocera and environmental data. Statistical analyses were conducted using the PAST software (Hammer et al., 2001).

\section{RESULTS}

\section{Environmental variables}

In general, the surveyed lakes were characterized by relatively low water transparency, with exception of lakes Aramuaca and Apastepeque, which showed Secchi depth $>6 \mathrm{~m}$ (Tab. 1). Secchi depth values ranging between 2.7$4.4 \mathrm{~m}$ were measured in 10 lakes, i.e. Lachuá, Atitlán, Ipala, Yojoa, Las Pozas, Calderas, El Pino, Magdalena, Quexil and Verde (Tab. 1). The waters of Lake Jucutuma (2.0 $\mathrm{m}$ depth) were characterized by visibility reaching the bottom, while four lakes were characterized by clarity of 1.5-1.8 m (Sacnab, Salpetén, Chicabal, Jocotal). The other lakes (Comandador, El Muchacho, El Rosario,
Grande, Chiligatoro, Madre Vieja, Ticamaya, Chanmico, El Espino, Los Negritos, Metapan, Olomega) were characterized by Secchi disk visibility $<1.0 \mathrm{~m}$ (Tab. 1).

The lakes investigated did not show considerable differences in $\mathrm{pH}$ values, which ranged from neutral (7.0 in Lake Salpetén) to alkaline (9.2 in Lake Chanmico and Lake Los Negritos, Tab. 1). Circumneutral water $\mathrm{pH}$ was recorded for lakes El Rosario, Ticamaya, Jucutuma, Comandador, Chiligatoro, Grande, Olomega, Verde and Lachuá. Waters of five lakes were strongly alkaline ( $\mathrm{pH}$ $\geq 9.0$ ), i.e., Sacnab, El Muchacho, Calderas, Los Negritos, and Chanmico. The other 14 lakes were characterized by slightly alkaline waters, with $\mathrm{pH}$ values ranging from 8.0 to 9.0 (Tab. 1). Electric conductivity ranged from $12 \mu \mathrm{S}$ $\mathrm{cm}^{-1}$, measured at Lake Chicabal, to $4520 \mu \mathrm{S} \mathrm{cm}^{-1}$ in Lake Salpetén (Tab. 1). High conductivity was recorded in the waters of El Rosario and Lachuá (Tab. 1). Values between $\sim 400$ and $600 \mu \mathrm{S} \mathrm{cm}^{-1}$ were determined in lakes Jocotal, Atitlan, El Muchacho, and Sacnab (Tab. 1). In the remaining lakes this parameter was $<350 \mu \mathrm{S} \mathrm{cm}^{-1}$ (Tab. 1). Ten of the sampled lakes were characterized by the dissolved oxygen content of over $5.0 \mathrm{mg} \mathrm{L}^{-1}$, i.e., El Espino, Magdalena, Sacnab, El Muchacho, Salpetén, Atitlán, Comandador, Las Pozas, Chicabal and Los Negritos (Tab. 1). The amount of dissolved oxygen in nineteen lakes ranged from $1.0 \mathrm{mg} \mathrm{L}^{-1}$ (Jucutuma) to $4.9 \mathrm{mg} \mathrm{L}^{-1}$ (Calderas). The lowest dissolved oxygen concentration $\left(<2.0 \mathrm{mg} \mathrm{L}^{-1}\right)$ were recorded in lakes Chiligatoro, El Rosario, Ticamaya and Jucutuma (Tab. 1).

\section{Subfossil Cladocera}

A total of 31 Cladocera taxa belonging to three families - Daphniidae, Bosminidae and Chydoridae - were found in the sediments of the lakes studied. Some Cladocera remains that could not be identified to species level belong to four different morphotypes and were referred to as "Not Recognized Remains" (NRR) 1, 2, 3 and 4, respectively (Fig. 2). Species relative abundances are presented in Fig. 3. Frequency (n), mean and maximum relative abundance of each Cladocera species are collated in Tab. 2.

The species richness per lake ranged from one in Lake Calderas to 12 species (lakes Atitlán and Verde), and included both planktonic and littoral forms. Only in the sediments of the deep Aramuaca crater lake no subfossil cladocerans remains were found. Planktonic species were represented by five taxa, i.e., Bosmina longirostris (O.F.Müller, 1785), Bosmina (E.) longispina (Leydig, 1860), Bosmina (E.) coregoni (Baird, 1857), group of Daphnia longispina (O.F. Müller, 1785), group of Daphnia pulex (Leydig, 1860), which occurred in 17 lakes (Fig. 3). Cladocera communities from lakes El Rosario and Calderas were entirely dominated by planktonic species (Fig. 3), while the share of Bosminidae and/or 
Daphniidae exceeded $90 \%$ in lakes Ipala, El Pino and Apastepeque (Fig. 3). Pelagic species were dominant (60$88 \%$ of total Cladocera abundance) in lakes Salpetén, Yojoa, El Espino, Atitlán, Sacnab, Chicabal, Lachuá (Fig. 3).

The remaining lakes (16) were dominated by littoral species of Chydoridae, which also represented the most species-rich group. In fact, 26 littoral Cladocera species and four NRR (Fig. 3 and Tab. 2) were identified in the sediments studied, with the NRR most likely belonging to also to littoral Chydoridae. Chydorus cf. sphaericus (O.F. Müller, 1776) (20 lakes), Alona glabra (Sars, 1901) (Ovalona glabra, following Sinev, 2015a) (13 lakes) and Cladocera comparable to (13 lakes) and Alona quadrangularis type (O.F. Müller, 1776) (12 lakes) were the most common taxa (Fig. 3 and Tab. 2). In five lakes (Las Pozas, Quexil, Verde, Chiligatoro, Magdalena), both littoral and planktonic species were present. The share of littoral species ranged from $60 \%$ to $80 \%$ in lakes Las Pozas,
Quexil, Verde and Chiligatoro. In the sediments of lakes Las Pozas and Quexil, eight and nine littoral species were identified, respectively, and two planktonic species were detected. In Las Pozas, Alona ossiani (Sinev, 1998), was the most abundant littoral species (approx. 20\%), whereas in Quexil - Chydorus cf. sphaericus (ca. 15\%) and Alona quadrangularis type (ca. 15\%, Fig. 3) were dominant. Lake Verde and Lake Chiligatoro were characterized by the presence of 12 and 6 species, respectively. Chydorus cf. sphaericus (ca. 25\%) and group of Anthalona verrucosa (Sars, 1901) (ca. 15\%) were the dominant species of the littoral zone in Lake Verde, while Alona ossiani (ca. $35 \%$ ) and Simocephalus sp. (Schoedler, 1858) (ca. 20\%) were the most abundant species in Lake Chiligatoro (Fig. 3 and Tab. 2). In Lake Magdalena, the deep-water species accounted for a minor portion of cladocerans, and Chydorus $\mathrm{cf}$. sphaericus was the dominant species (ca. 90\%). Planktonic taxa were completely absent in the sediments

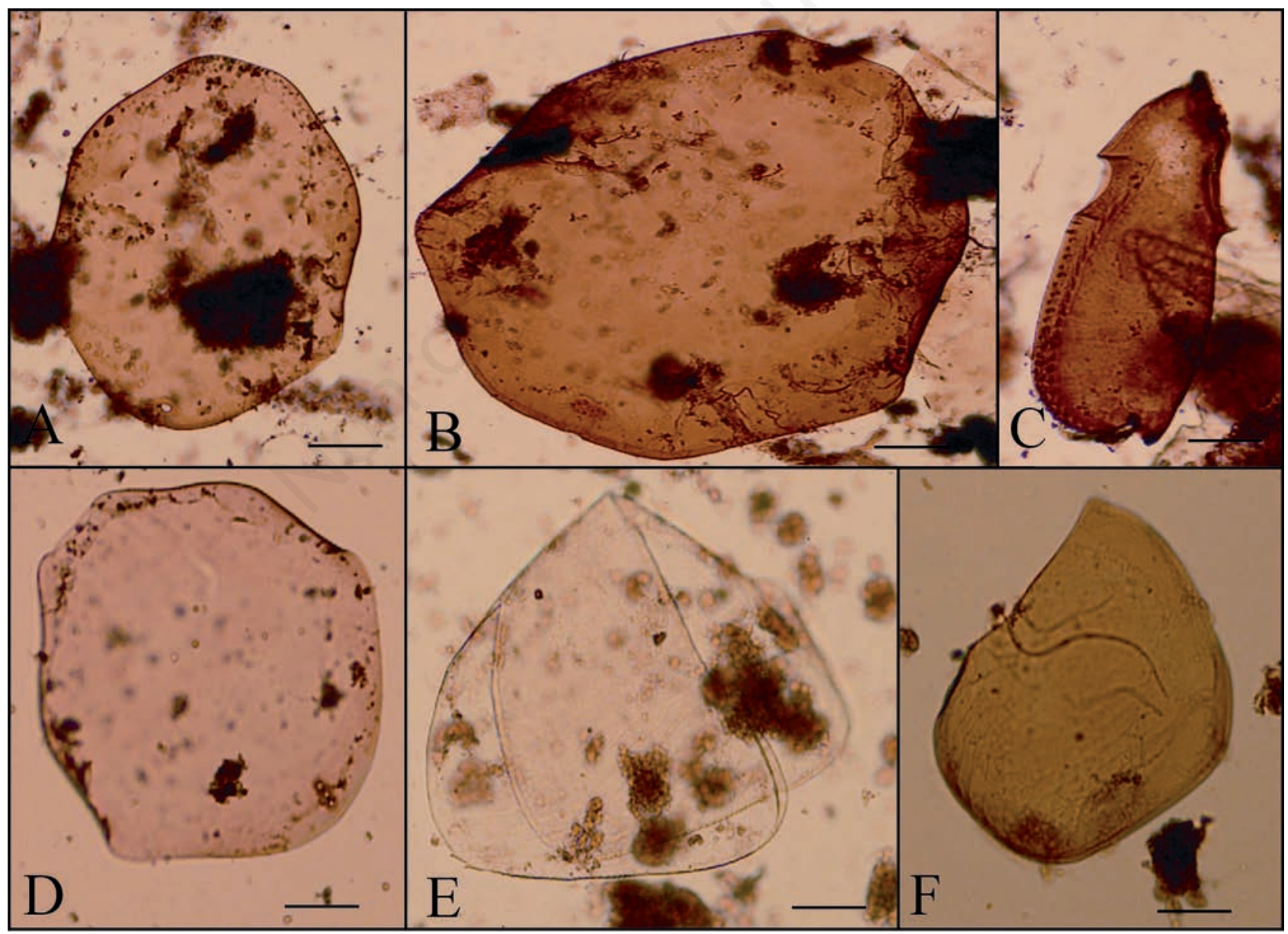

Fig. 2. Unidentified subfossil remains (NRR) of Cladocera. A) Probably headshield of Euryalona sp. B) Headshield NRR1. C) Postabdomen of Leydigiopsis ornata. D) Probably headshield of Leberis sp. E) NRR3, probably shell of Cladocera from group of Coronatella monacantha. F) shell NRR4. Scale bars: $500 \mu \mathrm{m}$. 
of eleven lakes (Fig. 3). Lakes Comandador, Los Negritos, Ticamaya and Jocotal were dominated by Chydorus cf. sphaericus, which represented from $36 \%$ to $50 \%$ of the Cladocera communities. This taxon was also common in Madre Vieja (15\%), Metapan (23\%) and Olomega (16\%). In Lake Madre Vieja, Alona ossiani was the most abundant species (ca. 42\%), Camptocercus dadayi (Stingelin, 1913) was the dominant species in Metapan (ca. 31\%), and NRR1 (ca. 32\%) (Figs. 2 and 3) were dominant in Olomega. In Lake Jucutuma, Acroperus sp. (Baird, 1843) (ca. 22\%) and Camptocercus dadayi (ca. 22\%) were dominant, whereas Alona quadrangularis type (ca. $43 \%$ ) and Alona glabra (ca. 29\%) dominated in Lake Grande. Lake El Muchacho and Lake Chanmico were characterized by low species diversity (3) and low frequency of individuals. Group of Leydigia acanthocercoides (Fischer, 1854) was dominant in Lake El Muchacho (ca. 52\%), whereas Leberis sp. (Smirnov, 1989) was the most prominent species in Lake Chanmico (50\%, Fig. 3). The largest num- ber of subfossil Cladocera remains was determined for Lakes Sacnab (22,000 ind. $\left.\mathrm{cm}^{-3}\right)$ and Ipala (21,000 ind. $\mathrm{cm}^{-3}$ ), where open-water species dominated. The maximum number of water fleas in the waterbodies dominated by littoral forms was ca. 10,000-11,000 ind. $\mathrm{cm}^{-3}$, as recorded in Madre Vieja, Quexil and Verde.

\section{Statistical analysis}

The "cophenetic coefficient" in the cluster analysis was 0.8009 and well reflected the similarities within the data. The dendrogram shown in Fig. 4 (see also Tab. 3) defined six Cladocera groups. The highest correlation coefficient between species was determined for Alona rustica (Scott, 1895) (group of Flavalona rustica, following Sinev and Dumont, 2016) and Simocephalus sp. (0.99, Group 6), and for Daphnia pulex-group and Bosmina longirostris (0.94, Group 1, Fig. 4a and Tab. 3). The species Bosmina (E.) coregoni, Bosmina (E.) longispina, Alona quadrangularis

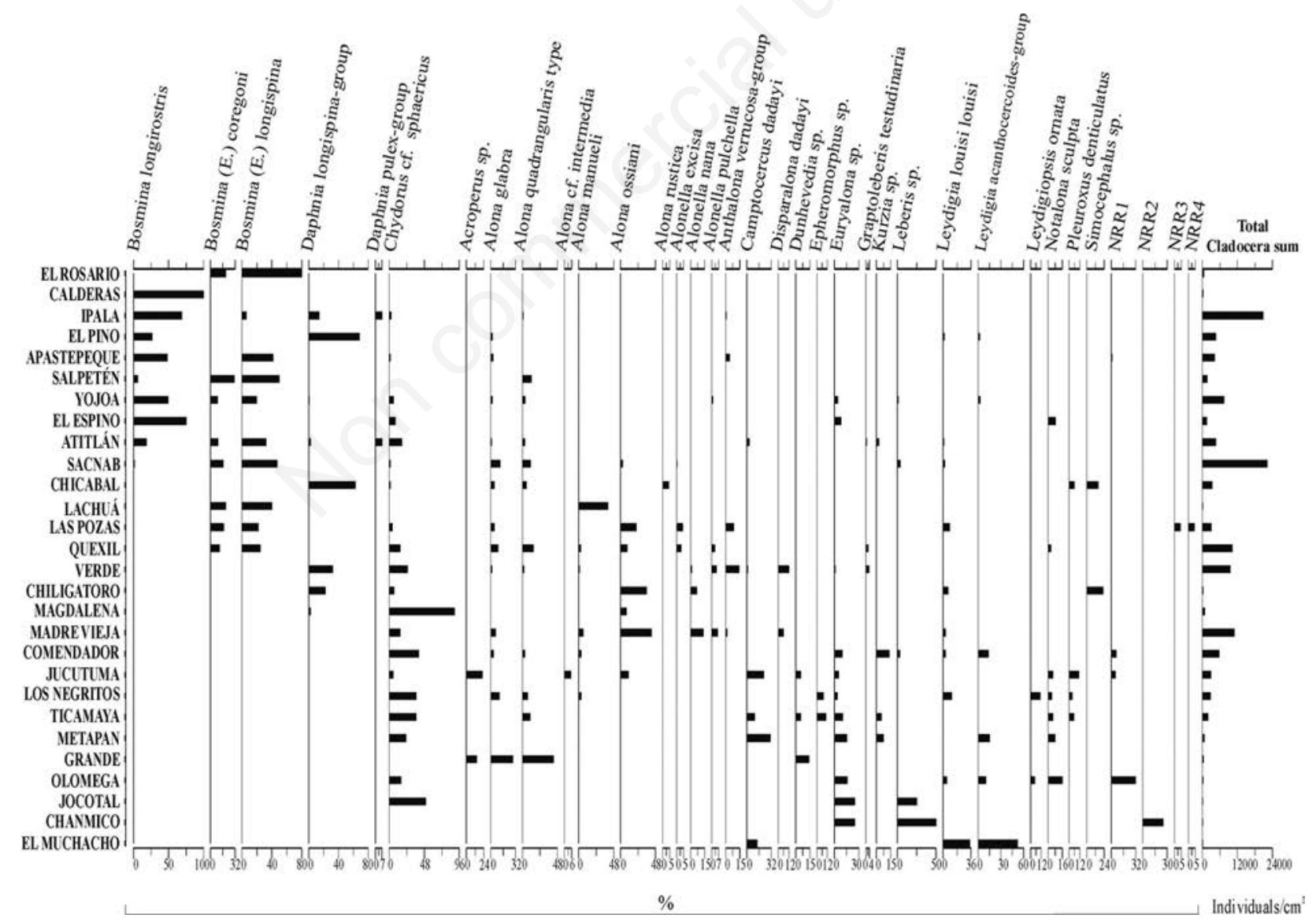

Fig. 3. Relative abundances (\%) diagram for the subfossil Cladocera species identified in surface sediments from freshwater ecosystems of Central America. Lakes are ordered by decreasing contribution of planktonic forms. NRR1, unidentified remains type 1; NRR2, unidentified remains type 2, probably headshield of Leberis sp.; NRR3, unidentified remains type 3, probably of Coronatella of monacantha-group); NRR4, unidentified remains type 4. 
type, Alona glabra and Leberis sp. (Group 2) resulted to be correlated at the similarity level of 0.92 . In the three other groups the correlation coefficient between species ranges between 0.8 and 0.86 (Fig. 4a).

The CCA analysis was conducted using the species included the six distinguished clusters and an additional set of other Cladocera species that were not included in any cluster. Due to their rarity and low contribution to total Cladocera remains, NRR were not included in the analysis. The CCA ordination biplot is presented in Fig. 4b. Arrows show environmental variables, and their length and direction indicate the strength and direction of their influence on the species composition (ter Braak, 1986).

Axis 1 and 2 explained almost $80 \%$ of the variability (axis $1=49.98 \%$, axis $2=29.29 \%$ ). Altitude, transparency, $\mathrm{pH}$ and the maximum depth were positively correlated with axis 1 , while conductivity and lake area were negatively correlated with the first canonical axis (Fig. 4b). The location of Group 1 in quadrant I, and of Group 3, Group 6 and the Daphnia longispina-group in quadrant IV underlines the positive correlation of the abundances of these species groups with altitude and negative correlation with conductivity. Moreover, the occurrence of Graptoleberis testudinaria (Fischer, 1848) and Group 1 also seem to be strongly determined by the Secchi disk visibility (Fig. 4b). Species and groups of Cladocera located in quadrants II and III were correlated negatively with altitude (Fig. 4b) and positively with conductivity and lake area (Fig. 4b and Tab. 3). Group 2 and Alonella excisa (Fischer, 1854) were placed in the $2^{\text {nd }}$ quarter. Species of Group 4 and 5 and Epheromorphus sp. (Frey, 1982), Leydigia louisi louisi (Jenkin, 1934), Leydigiopsis ornata (Daday, 1905), Notalona sculpta (Sars, 1901) were located in the $3^{\text {rd }}$ quarter. According to Fig. $4 \mathrm{~b}$, these species dominated in lowlands and in the waters with low visibility (negative correlation with Secchi disk visibility and altitude). Chydorus cf. sphaericus was located between quadrants III and IV, which may indicate a weak relation with all of the considered environmental variables.

\section{DISCUSSION}

Thirty-one Cladocera species were identified in surface sediments of the lakes studied. The number of species found in individual lakes was generally small. In fact, the maximum number of species found in lakes Atitlán and Verde was only 12. Compared to European lakes, which are normally inhabited by over 30 species (Dumont, 1994), the species diversity of Cladocera was low in the considered region of Central America. These findings seems to confirm that the number of Cladocera species found in one waterbody in the Neotropics is in general low and usually ranges from several to over a dozen species (Cuna et al., 2014; Peréz et al., 2013; Zawisza et al., 2012). The differences in the number of cladoceran species between the con- tinents may result from species competition (Feniova et al., 2011; Shurin, 2000), fish or invertebrate predation (Korhola and Rautio, 2001), as well as from different geological history of the area (Korhola and Rautio, 2001).

The identified Cladocera included both littoral and pelagic species. Planktonic species of Daphniidae and Bosminidae were the most abundant. Remains of the Daphnia pulex-group and the Daphnia longispina-group were mainly associated to lakes located at altitudes above

Tab. 2. Number of occurrences, maximum and mean percentage contribution of cladoceran species identified in the sediments of the surveyed waterbodies.

\begin{tabular}{|c|c|c|c|}
\hline Group or species & n & $\begin{array}{c}\text { Max } \\
(\%)\end{array}$ & $\begin{array}{c}\text { Mean } \\
(\%)\end{array}$ \\
\hline Bosmina longirostris & 9 & 100.0 & 43.8 \\
\hline Bosmina (E.) coregoni & 8 & 31.3 & 17.0 \\
\hline Bosmina (E.) longispina & 10 & 80.0 & 36.2 \\
\hline Daphnia longispina-group & 8 & 67.9 & 25.6 \\
\hline Daphnia pulex-group & 2 & 7.0 & 7.0 \\
\hline Chydorus cf. sphaericus & 20 & 89.5 & 19.7 \\
\hline Acroperus sp. & 3 & 22.2 & 12.2 \\
\hline Alona glabra & 13 & 28.6 & 6.7 \\
\hline Alona quadrangularis type & 12 & 42.9 & 10.7 \\
\hline Alona $\mathrm{cf}$. intermedia & 1 & 5.6 & - \\
\hline Alona manueli & 6 & 40.0 & 9.6 \\
\hline Alona ossiani & 8 & 42.4 & 16.4 \\
\hline Alona rustica & 1 & 4.3 & - \\
\hline Alonella excisa & 3 & 4.3 & 2.5 \\
\hline Alonella nana & 3 & 13.6 & 7.1 \\
\hline Alonella pulchella & 4 & 6.1 & 3.7 \\
\hline Anthalona verrucosa-group & 5 & 14.3 & 5.9 \\
\hline Camptocercus dadayi & 6 & 30.8 & 13.7 \\
\hline Disparalona dadayi & 2 & 11.9 & 9.0 \\
\hline Dunhevedia sp. & 3 & 14.3 & 8.4 \\
\hline Ephemeroporus sp. & 2 & 10.5 & 9.0 \\
\hline Euryalona sp. & 11 & 25.0 & 11.3 \\
\hline Graptoleberis testudinaria & 3 & 3.6 & 2.5 \\
\hline Kurzia sp. & 4 & 13.3 & 7.2 \\
\hline Leberis sp. & 5 & 50.0 & 16.6 \\
\hline Leydigia louisi louisi & 10 & 34.4 & 7.8 \\
\hline Leydigia acanthocercoides-group & 6 & 51.7 & 15.9 \\
\hline Leydigiopsis ornata & 2 & 11.1 & 8.1 \\
\hline Notalona sculpta & 7 & 15.9 & 7.1 \\
\hline Pleuroxus denticulatus & 4 & 11.1 & 6.4 \\
\hline Simocephalus sp. & 2 & 22.4 & 19.0 \\
\hline NRR1 & 4 & 31.8 & 11.4 \\
\hline NRR2 & 1 & 25.0 & - \\
\hline NRR3 & 1 & 4.3 & - \\
\hline NRR4 & 1 & 4.3 & - \\
\hline
\end{tabular}

n, occurrence; NRR1-4, not recognize remains type 1 to 4; NRR2, probably headshield of Leberis sp.; NRR3, probably Coronatella monacantha (Sars 1901) group. 

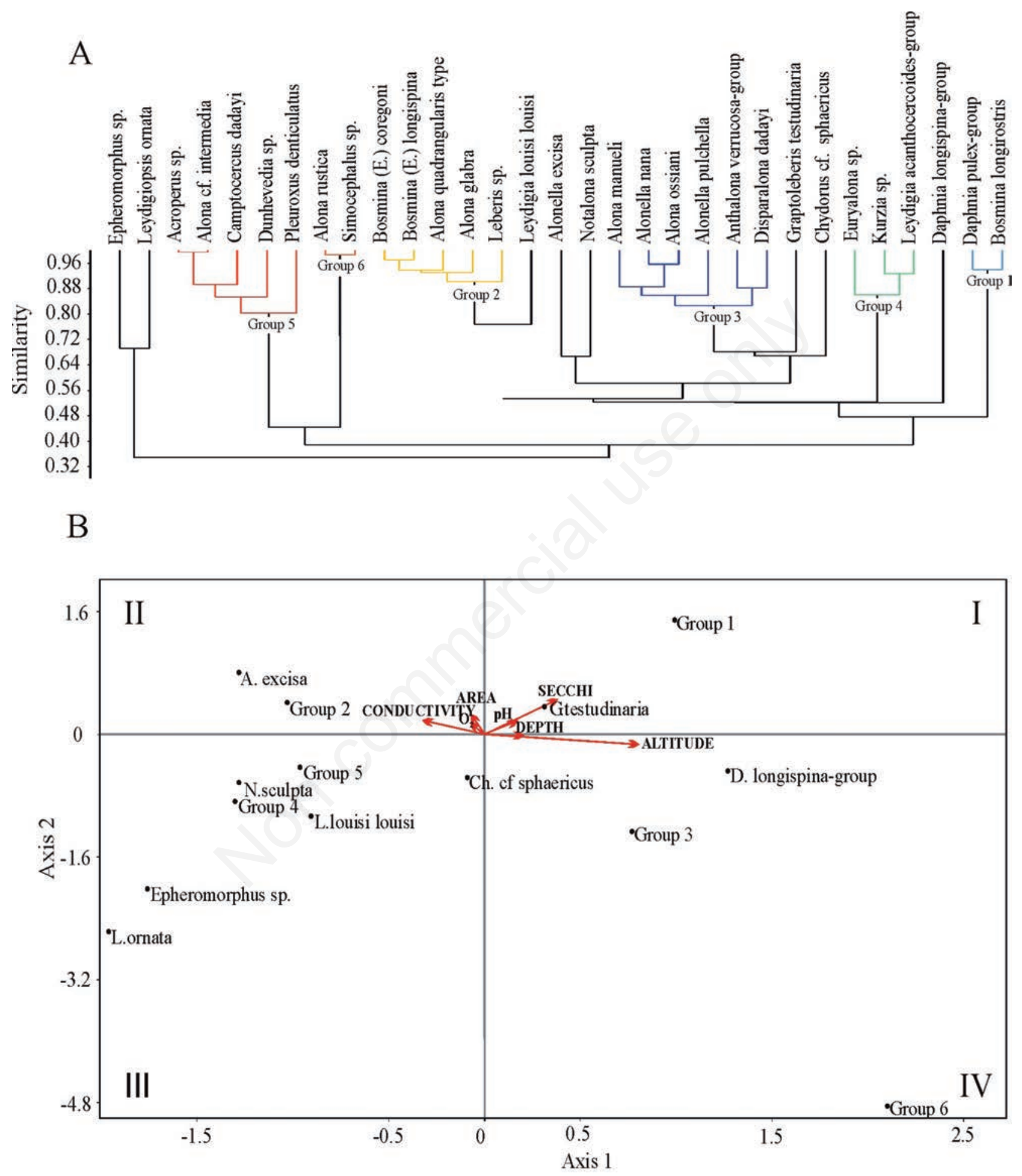

Fig. 4. Results of multivariate statistical analysis applied to qualitative and quantitative results of species composition of subfossil Cladocera, and environmental variables. A) Cluster analysis showing species grouping according to reciprocal correlation level; the groups were distinguished for species that showed a high level of similarity $>0.8$; species composition of each group is presented in Tab. 3; B) Canonical correspondence analysis (CCA) for species relative abundances and environmental variables; length and direction of arrows show respectively the strength and direction of a certain environmental variable. 
$1000 \mathrm{~m}$ asl. CCA analysis showed the preference of the Daphnia pulex-group for clear waters, such as lakes Atitlán and Ipala, that showed transparency of $4.2 \mathrm{~m}$ and 3.6 $\mathrm{m}$, respectively. Moreover, the contribution of Daphniidae was negatively correlated with conductivity and was higher in waters with conductivity $\leq 100 \mu \mathrm{S} \mathrm{cm}^{-1}$. The results show the preference of Daphniidae for highlands and mountain areas and clean, low-mineralized and nutrientpoor waters. Similar environmental preferences by Daphniidae were also suggest by Hart (2004) and by Mergeay et al. (2005) for African lakes. The occurrence of Daphniidae species in lakes of Central American highlands was also observed by Peréz et al. (2013).

Bosminidae species were observed along the whole altitudinal gradient of the lake studied, from lowland, to highland and mountain lakes. CCA analysis revealed a negative correlation of Eubosmina (Bosmina (E.) coregoni, Bosmina (E.) longispina) and a positive correlation of Bosmina longirostris with altitude. Eubosmina was found in six lowland lakes, but also in two lakes located at $>1000 \mathrm{~m}$ asl (Atitlán and Ipala), in Lake Yojoa (639 $\mathrm{m}$ asl) and in Lake Apastepeque $(509 \mathrm{~m}$ asl). This suggests that even though $\mathrm{Eu}$ bosmina prefered lakes located at a lower altitude, this is probably not the main factor determining the distribution of this genus. On the other hand, Eubosmina mainly occurred in waters with high conductivity. These species were dominant in highly mineralized $\left(4520 \mu \mathrm{S} \mathrm{cm}^{-1}\right)$ and brackish ( salinity $=2.5 \%$ ) waters of Lakes Salpetén, as well as in El Rosario and Lachuá, which showed conductivity values $>900 \mu \mathrm{S} \mathrm{cm}^{-1}$. The presence of Eubosmina, along with Bosmina longirostris in Lake Salpetén, confirms the tolerance of Bosminidae to waters with high mineral content and/or salinity (Aladin, 1991). The obtained results also confirm the wide distribution of planktonic Daphniidae and Bosminidae in Central America (Elías-Gutiérrez et al., 1999; Korovchinsky, 2006).

Chydoridae was the most species rich group of Cladocera in the sediment studied. Chydorus cf. sphaericus was the most common species, as it was present in 20 out of the 29 surveyed lakes located both in lowland and mountain areas. The relative abundance of Chydorus cf. sphaericus in the lake located at the highest altitude (Lake Magdalena, $2863 \mathrm{~m}$ asl) was almost $90 \%$. CCA analysis showed that none of the measured environmental factors had a significant effect on the distribution of the species in the region studied of Central America. This confirmed the ubiquity of Chydorus cf. sphaericus and its wide range of tolerance to environmental and ecological conditions (Flössner, 2000; Fryer, 1968; Korhola and Rautio, 2001; Zawisza and Szeroczyńska, 2011).

The genus Alona was mostly represented by Alona glabra and the Alona quadrangularis type. These species were found in 13 and 12 lakes, respectively, which were characterized by different conductivity, oxygenation, water visibility and altitude. The Alona quadrangularis type was the unique littoral species found in Lake Salpetén, which may indicate its tolerance to waters with higher mineralization. The genus Alona was also represented by Alona manueli (Sinev and Zawisza, 2013) and Alona ossiani, which, based on the cluster analysis, were grouped together, along with Alonella nana (Baird, 1843), Alonella pulchella (Herrick, 1884), the Anthalona verrucosa-group and Disparalona dadayi (Birge, 1910). The multivariate analysis showed a negative correlation between Group 3 and lake conductivity, which most likely resulted from the presence of species included in Group 3 in lakes with conductivity $\leq 100 \mu \mathrm{S} \mathrm{cm}^{-1}$ and with medium conductivity $\left(204-331 \mu \mathrm{S} \mathrm{cm}^{-1}\right)$. Lake Sacnab $(412 \mu \mathrm{S}$ $\left.\mathrm{cm}^{-1}\right)$ and Lake Lachuá $(906 \mu \mathrm{S} / \mathrm{cm})$ are exceptions, and two species from Group 3 (i.e., Alona ossiani and Alona manueli, respectively) were present.

Sinev (1998) showed that Alona ossiani belongs to the Alona affinis complex, which is considered an oligotrophic species in Eurasia (Kamenik et al., 2007; Korhola and Rautio, 2001). On the other hand, Alona manueli (an endemic species of Central America) and Alonella pulchella were identified in oligotrophic lakes in Mexico (Cuna et al., 2014; Sinev and Zawisza, 2013). Moreover, this studied provided the first record of Alonella pulchella in the tropical region, as previously this species was recorded only in Canada (Korosi and Smol, 2012). The obtained results seem to confirm the preference of these species for waters of low trophic status. The negative correlation of Group 3 with the lake area may indicate the preference of these species for smaller lakes with well-developed littoral zone. In particular, Alonella

Tab. 3. Groups of species correlated with each other at the minimum level of 0.8 and distinguished based on the cluster analysis.

\begin{tabular}{ll} 
Group & Species composition \\
1 & Daphnia pulex-group, Bosmina longirostris \\
2 & Bosmina (E.) coregoni, Bosmina (E.) longispina, Alona glabra, Alona quadrangularis type, Leberis sp. \\
\hline 3 & Alona manueli, Alona ossiani, Alonella nana, Alonella pulchella, Anthalona verrucosa-group, Disparalona dadayi \\
\hline 5 & Euryalona sp., Kurzia sp., Leydigia acanthocercoides-group \\
6 & Acroperus sp., Alona cf. intermedia, Camptocercus dadayi, Dunhevedia sp., Pleuroxus denticulatus \\
\hline
\end{tabular}


nana, was present in only three small lakes with area $\leq 0.1 \mathrm{~km}^{2}$. This suggests that, similarly to what observe in Europe, Alonella nana may prefer small lakes (Fryer, 1968; Korosi and Smol, 2012). Furthermore, the presence of Alona ossiani in mountain lakes may indicate a pronounced tolerance toward the harsher climatic conditions determined by altitude. The Eurasian species Alona affi$n i s$, is considered to tolerate lower temperatures (Kamenik et al., 2007; Locke and Sprules, 2000) and the results of the present study indicated that Allona ossiani shows similar characteristics in Central America.

Leydigia louisi louisi and Leydigia acanthocercoidesgroup played a significant role in Lake El Muchacho (almost $90 \%$ ), which was characterized by a water transparency of only $0.4 \mathrm{~m}$. Moreover, these species were relatively abundant $(>10 \%)$ in other lakes with water transparency below $0.9 \mathrm{~m}$. The CCA analysis confirmed the preference of these species for waters with lower Secchi visibility. The presence of a species characteristic of Central America such as Leydigiopsis ornata, which is a typical benthic species (Van Damme and Dumont, 2010), was recorded only in 2 shallow ( $<2.5 \mathrm{~m}$ water depth) and scarcely transparent lakes, which were characterized (Secchi depth $<1 \mathrm{~m}$ ). Graptoleberis testudinaria, which was recorded in the sediments of Lakes Atitlán, Quexil and Verde, preferred waters with higher Secchi visibility $(\geq 2.7 \mathrm{~m})$, as showed also by the CCA analysis. However, the results of the multivariate statistical analysis are highly controversial, because Garptoleberis testudinaria is commonly considered to be associated with aquatic vegetation (Fryer, 1968; Rybak and Błędzki, 2016). This suggests that other factors not included in our analysis control the distribution of this species.

Pleuroxus denticulatus (Birge, 1879) remains were identified in the sediments from four lakes (Chicabal, Jucutuma, Ticamaya, Los Negritos) and its maximum contribution to the Cladocera communities did not exceed $12 \%$ (average $=6.4 \%$ ). The presence of only one Pleuroxus species in the lakes of the study area and its local distribution confirms the rarity of this Cladocera group in the tropical region (Korovchinsky, 2006).

Canonical correspondence analysis outlined altitude as a key driver of the cladoceran fauna of in Central America. Other significant environmental factors affecting the Cladocera distribution were water transparency and conductivity. Among the environmental variables considered in this study, the less significant in affecting the waterflea population in the study area was the concentration of dissolved oxygen.

\section{CONCLUSIONS}

This study showed a relatively typical distribution of Cladocera in lakes of the Neotropic region. In summary, our results indicate that: i) the most common Cladocera species of the study area was Chydorus cf. sphaericus, likely in relation to the ability of this species to adapt to different ecological conditions; ii) planktonic species of Daphniidae and Bosminidae were the most abundant; iii) Daphniidae species were recorded primarily in highland lakes; iv) Eubosmina and the Alona quadrangularis type showed pronounced tolerance to waters with high mineralizatiovn level; e) Alona ossiani, Alona manueli, Alonella nana and Alonella pulchella were negatively correlated with water conductivity; vi) the presence of Alonella nana was restricted to lakes with a smaller surface area; vii) Alona ossiani was an important subdominant species in shallow lakes located at high altitudes; viii) among the environmental variables considered, altitude was a key driving factor for distribution of the Cladocera fauna whereas dissolved water oxygenation was almost insignificant.

These results provide basic information on Cladocera communities in freshwater ecosystems of Central America, a region where research carried out so far is insufficient to provide robust taxonomical and ecological information.

\section{ACKNOWLEDGMENTS}

The study was funded by the Polish Ministry of Science (Grant NCN 2014/13/B/ST10/02534) and the German Research Foundation (DFG, SCHW 671/16-1). Furthermore, scientific cooperation was supported by the Polish - German governments (MNiSW-DAAD, 2016-2017). We would like to thank Prof. A.Y. Sinev and Prof. A.A. Kotov for their help with identification of specimens. Special thanks is due to to Cuauhtémoc Ruiz (Instituto Tecnológico de Chetumal), Ramón Beltrán (Centro Interdisciplinario de Ciencias Marinas, Mexico), and Lisa Heise (Universidad Autónoma de San Luis Potosí, Mexico) for their excellent work on field. We also like to thank all people involved in this work: Margarita Caballero (Instituto de Geofísica, UNAM), Alexis Oliva and the team from the Asociación de Municipios del Lago de Yojoa y su área de influencia (AMUPROLAGO, Honduras), María Reneé Alvarez, Margarita Palmieri, Eleonor de Tott (Universidad del Valle de Guatemala, Guatemala), Consejo Nacional de Áreas Protegidas (CONAP, Guatemala), Néstor Herrera and Ministerio de Medio Ambiente (San Salvador, El Salvador). CONACYT (Mexico) provided fellowship (218604, 405326) for the third and fourth authors.

\section{REFERENCES}

Aladin NV, 1991. Salinity tolerance and morphology of the osmoregulation organs in Cladocera with special reference to Cladocera from the Aral Sea. Hydrobiologia 225:291-299.

Bigler C, Heiri C, Krskova R, Lotter AF, Sturm M, 2006. Dis- 
tribution of diatoms, chironomids and Cladocera in surface sediments of thirty mountain lakes in south-eastern Switzerland. Aquat. Sci. 68:154-171.

Bjerring R, 2007. Lake response to global change: nutrient and climate effects using cladoceran (Crustacea) subfossils as proxies. PhD Thesis, National Environmental Research Institute University of Aarhus, Denmark.

Campanelli Mortari R, Henry R, 2016. Horizontal distribution of Cladocera in a subtropical lake marginal to a river. J. Paleolimnol. 75:109-120.

Cuna E, Zawisza E, Caballero M, Ruiz-Fernández AC, LozanoGarcía S, Alcocer J, 2014. Environmental impacts of Little Ice Age cooling in central Mexico recorded in the sediments of a tropical alpine lake. J. Paleolimnol. 51:1-14.

Dumont HJ, 1994. On the diversity of the Cladocera in the tropics. Hydrobiologia 272:27-38.

Elías-Gutiérrez M, Ciros-Pérez J, Suárez-Morales E, Silva-Briano M, 1999. The freshwater Cladocera orders Ctenopoda and Anomopoda) of Mexico, with comments on selected taxa. Crustacean 72:171-186.

Elías-Gutiérrez M, Kotov AA, Garfias-Espejo T, 2006. Cladocera (Crustacea: Ctenopoda: Anomopoda) from southern Mexico, Belize and Northern Guatemala.Zootaxa 119: $1-27$.

Elías-Gutiérrez M, Suárez-Morales E, Gutiérrez-Aguirre MA, Silva-Briano M, Granados-Ramírez JG, Garfias-Espejo T, 2008. [Cladocera y Copepoda de las aguas continentales de México].[Book in Spanish]. Universidad Nacional Autónoma de México: 322 pp.

Feniova IY, Razlutsky VI, Palash AL, 2011. Temperature effects of interspecies competition between Cladoceran species in experimental conditions. Inland Water. Biol. 4:65-71.

Flössner D, 2000. [Die Haplopoda und Cladocera (ohne Bosminidae) Mitteleuropas].[Book in German]. Backhuys Publisher, Leiden: 428 pp.

Frey DG, 1986. Cladocera analysis, p. 667-692. In: B.E. Berglund (ed.), Handbook of Holocene palaeoecology and palaeohydrology. J. Wiley \& Sons, Chichester.

Frolova L, Nazarova L, Pestryakova L, Herzschuh U, 2014. Subfossil Cladocera from surface sediment in thermokarst lakes in northern Siberia, Russia, in relation to limnological and climatic variables, J. Paleolimnol. 52:107-119.

Fryer G, 1968. Evolution and adaptive radiation in the Chydoridae (Crustacea: Cladocera): a study in comparative functional morphology and ecology. Philos. T. R. Soc. B 254:221-385.

Green J, 1995. Altitudinal distribution of tropical planktonic Cladocera. Hydrobiologia 307:75-84.

Hammer O, Harper DAT, Ryan PD, 2001. Past Paleontological Statistics Software Package for Education and Data Analysis. Palaeontol. Electron. 4:4-9.

Hart RC, 2004. Cladoceran periodicity patterns in relation to selected environmental factors in two cascading warm-water reservoirs over a decade, Hydrobiologia 526:99-117.

Hudec I, 2000. Subgeneric differentiation within Kurzia (Crustacea: Anomopoda: Chydoridae) and a new species from Central America. Hydrobiologia 421:165-178.

Jeppesen E, Leavitt P, De Meester L, Peder Jensen J, 2001. Functional ecology and paleolimnology: using Cladocera remains to reconstruction anthropogenic impact. Trends Ecol. Evol. 16:191-198.
Juggins S, 2005. New features in C2 version 1.4. University of Newcastle.

Juggins S, 2007. User guide C2 Software for ecological and paleoecological data analysis and visualisation User guide Version 1.5. University of Newcastle.

Kamenik C, Szeroczyńska K, Schmidt R, 2007. Relationships among recent Alpine Cladocera remains and their environment: implications for climate-changes studies. Hydrobiologia 594:33-46.

Karmalkar AV, Bradley RS, Diaz HF, 2011. Climate change in Central America and Mexico: regional climate model validation and climate change projections. Clim. Dyn. 37:605-629.

Kienast F, Wetterich S, Kuzmina S, Schirrmeister L, Andreev AA, Tarasov P, Nazarova L, Kossler A, Frolova L, Kunitsky VV, 2011. Paleontological records prove boreal woodland under dry inland climate at today's Arctic coast in Beringia during the last interglacial. Quat. Sci. Rev. 30:2134-2159.

Kotov AA, Elías-Gutiérrez M, Guadalupe Nieto M, 2003. Leydigia louisi louisi Jenkin, 1934 in the Neotropics, L. louisi mexicana n. subsp. in Central Mexican highlands. Hydrobiologia 510:239-255.

Kotov AA, 2009. A revision of Leydigia Kurz, 1875 (Anomopoda, Cladocera, Branchiopoda), and subgeneric differentiation within the genus. Magnolia Press: $84 \mathrm{pp}$.

Korhola A, 1999. Distribution patterns of Cladocera in subarctic Fennoscandian lakes and their potential in environmental reconstruction. Ecography 22:357-373.

Korhola A, Rautio M, 2001. Cladocera and other Branchiopod crustaceans, p. 5-41. In: J.P. Smol, J.B. Birks and W.M. Last (eds.), Tracking environmental change using lake sediments. Zoological indicators. Kluwer Academic, Dordrecht.

Korosi JB, Smol JP, 2012. An illustrated guide to the identification of cladoceran subfossil from lake sediments in northeastern North America: part 2 - the Chydoridae, J. Paleolimnol. 48:587-622.

Korovchinsky NM, 2006. The cladocera (Crustacea: Brachiopoda) as a relict group. Zool. J. Linn. Soc. 147:109-124.

Locke A, Sprules WG, 2000. Effects of acidic pH and phytolankton on survival and condition of Bosmina longirostris and Daphnia pulex. Hydrobiologia. 437:187-196.

Luoto T, Sarmaja-Korjonen K, Nevalainen L, Kauppila T, 2009. A 700 year record of temperature and nutrient changes in a small eutropied lake in southern Finland. Holocene 19:1063-1072.

Mergeay J, Verschuren D, De Meester L, 2005. Daphnia species diversity in Kenya, and a key to the identification of their ephippia. Hydrobiologia 542:261-274.

Mirosław-Grabowska J, Zawisza E, 2014. Late Glaciale early Holocene environmental changes in Charzykowskie Lake (northern Poland) based on oxygen and carbon isotopes and Cladocera data. Quat. Int. 328-329:156-166.

Nováková K, Van Hardenbroek M, van der Knaap WO, 2013. Response of subfossil Cladocera in Gerzensee (Swiss Plateau) to early Late Glacial environmental change. Palaeogeogr. Palaeoclimatol. Palaeoecol. 391:84-89.

Padhye SM, Kotov AA, Dahanukar N, Dumont HJ, 2016. Biogeography of the 'water flea' Daphnia O.F. Müller, (Crustacea: Branchiopoda: Anomopoda) on the Indian subcontinent. J. Limnol. 75:1476.

Paterson MJ, 1994. Paleolimnological reconstruction of recent changes in assemblages of Cladocera from acidified lakes 
in the Adirondack Mountains (New York). J. Paleolimnol. 11:189-200.

Peréz L, Lorenschat J, Massaferro J, Pailles Ch, Sylvestre F, Hollwedel W, Brandorff GO, Brenner M, Islebe G, Lozano MS, Scharf B, Schwalb A, 2013. Bioindicators of climate and trophic state in lowland and highland aquatic ecosystems of the Northern Neotropics. Rev. Biol. Trop. 61:603-644.

Rajapaksa R, Fernando CH, 1987. Redescription and assignment of Alona globulosa Daday, 1898 to a new genus Notoalona and a description of Notoalona freyi sp.nov. Hydrobiologia 144:131-153.

Rey J, Vasquez E, 1986. [Contribution à la connaissance des Cladocères néotropicaux: redescription de Leydigiopsis ornata Daday, 1905. (Crustacea, Cladocera)].[Article in Fench]. Ann. Limnol. 22:169-176.

Rybak JI, Błędzik LA, 2016. Freshwater Crustacean zooplankton of Europe. Springer: 918 pp.

Schmidt R, Müller J, Drescher-Schneider R, Krisai R, Szeroczyńska K, Barić A, 2000. Changes in lake level and trophy at Lake Vrana, a large karstic lake on the Islanad of Cres (Croatia), with respect to palaeoclimate and anthropogenic impacts during the last approx. 16,000 years. J. Limnol. 59:113-130.

Shurin JB, 2000. Dispersal limitation, invasion resistance, and the structure of pond zooplankton comunities. Ecology 81:3074-3086.

Sinev AY, 1998. Alona ossiani sp. n., a new species of the Alona affinis complex from Brazil, deriving from the collection of G.O. Sars (Anomopoda Chydoridae). Arthropoda Sel. 7:103-110.

Sinev AY, 2001. Redescripton of Alona glabra Sars, 1901, a South American species of the pulchella group (Branchiopoda: Anomopoda: Chydoridae). Arthropoda Sel. 10:273-280.

Sinev A, Zawisza E, 2013. Comments on cladocerans of crater lakes of the Nevado de Toluca Volcano (Central Mexico), with the description of a new species, Alona manueli sp. Nov. Zootaxa 3647:390-400.

Sinev A Y, 2015a. Revision of the pulchella-group of Alona s. lato leads to its translocation to Ovalona Van Damme et Dumont, 2008 (Branchiopoda: Anomopoda: Chydoridae). Zootaxa 4044:451-492.

Sinev AY, 2015b. Morphology and phylogenetic position of three species of genus Camptocercus Baird, 1843 (Cladocera: Anomopoda: Chydoridae). Zootaxa 4040:169-186.

Sinev AY, Dumont HG, 2016. Revision of the costata-group of Alona s. lato (Cladocera: Anomopoda: Chydoridae) confirms its generic status. Eur. J.Taxon. 223:1-38.

Sinev AY, Silva-Briano M, 2012. Cladocerans of genus Alona Baird, 1843 (Cladocera: Snomopoda: Chydoridae) and related genera from Aguascalientes State, Mexico. Zootaxa. 3569:1-24.

Sweetman JN, Rühland KM, Smol JP, 2010. Environmental and spatial factors influencing the distribution of cladocerans in lakes across the central Canadian Arctic treeline region. J. Limnol. 69:76-87.
Szeroczyńska K,1991. Impact of prehistoric settlements on the Cladocera in the sediments of Lakes Suszek, Błędowo, and Skrzetuszewskie. Hydrobiologia 225:105-114.

Szeroczyńska K, Tatur A, Weckstrom J, Gąsiorowski M, Noryśkiewicz A, Sienkiewicz E, 2007. Holocene environmental history in northwest Finnish Lapland reflected in the multi-proxy record of small subartic lake. J. Paleolimn. 38:25-47.

Szeroczyńska K, Zawisza E, 2011a. Subfossil faunal and floral remains (Cladocera, Pediastrum) in two northern Lobelia lakes in Finland. Knowl. Manag. Aquat. Ect. 403:09.

Szeroczyńska K, Zawisza E, 2011b. Records of the 8200 cal BP cold event reflected in the compositionof subfossil Cladocera in the sediments of three lakes in Poland. Quat. Int. 233:185-193.

Szeroczyńska K, Zawisza E, Wojewódka M, 2015. Initial time of two high altitude crater lakes (Nevado De Toluca, Central Mexico) recorded in subfossil Cladocera. Stud. Quatern. 32:109-116.

Taylor MA, Alfaro EJ, 2005. Climate of Central America and the Caribbean, p. 181-189. In: J.E. Oliver (ed.), Encyclopedia of world climatology. Springer, Dordrecht.

ter Braak CJF, 1986. Canonical correspondence analysis: a new eigenvector technique for multivariate direct gradient analysis. Ecology 67:1167-1179.

Van Damme KV, Dumont HJ, 2010. Cladocera of the Lençóis Maranhenses (NE - Brazil): faunal composition and a reappraisal of Sars' method. Braz. J. Biol. 70:755-779.

Van Damme KV, Sinev AY, Dumont HJ, 2011. Separation of Anthalona gen.n. from Alona Baird, 1843 (Branchiopoda: Cladocera: Anomopoda): morphology and evolution of scraping stenothermic alonines. Zootaxa 2875:1-64.

Zawiska I, Słowiński M, Correa-Metrio A, Obremska M, Luoto T, Nevalainen L, Woszczyk M, Milecka K, 2015. The response of a shallow lake and its catchment to Late Glacial climate changes - A case study from eastern Poland. Catena 126:1-10.

Zawisza E, Szeroczyńska K, 2011. Cladocera species composition in lakes in the area of the Hornsund Fjord (Southern Spitsbergen)-Preliminary results, Knowl. Manag. Aquat. Ec. 402:04.

Zawisza E, Caballero M, Ruiz-Fernandez C, 2012. 500 years of ecological changes recorded in subfossil Cladocera in a high-altitude tropical lake Lago de La Luna, Central Mexico. Stud. Quatern. 29:23-29.

Zawisza E, Correa-Metrio A, Caballero M, Lozano S, Szeroczyńska K, 2014. Paleoecology of tropical Lake Zirhauen (Western Mexico) recorded in Cladocera remains. Abstract book of the 8th Shallow lakes Conf., Antalya, Turkey.

Zawisza E, Cuna E, Caballero M, Ruiz-Fernandez AC, Szeroczyńska K, Woszczyk M, Zawiska I, 2016. Environmental changes during the last millennium recorded in subfossil Cladocera, diatoms and sediment geochemistry from Lake El Sol (Central Mexico). Geol. Q. (in press). 